\title{
Nonuse of an Academic
}

Library

"What is a noncustomer? These definitions may be clues to turning a noncustomer into a customer: (1) He doesn't know about your product; (2) he can't find your product; (3) he doesn't need your product; (4) he doesn't understand what your product can do for him; (5) he doesn't expect good service; (6) he has had trouble with your product; (7) he doesn't know your brand; (8) he doesn't trust your brand; (9) he thinks the product's value is uncompetitive; or (10) he simply prefers a competitive product."-News from the Darnell Institute of Business Research.

W dreds of stucies about the characterisdreds of studies about the characteristics of library users conducted either by consulting agencies or individual libraries, little has been said or done about the library nonuser. He is a creature that exists on every campus, from the freshman to the faculty emeritus level, popping up usually at disconcerting times with ingenious comments to deans and presidents about how he got or is getting through college without ever using the library. Also, there are the ubiquitous master's or doctoral degree candidates who stumble into a conversation with a librarian and who are overjoyed to hear about Dissertation $\mathrm{Ab}$ stracts or Engineering Index.

As to the extent of nonuse, the truth is that for every one of the self-declared (even proud) nonusers, there are probably dozens that silently manage to get by without the library.

At the time this article was written $\mathrm{Mr}$. Lubans was head of reader services division at Rensselaer Polytechnic Institute Library, Troy, New York. He is now assistant director for public services at the University of Colorado Library, Boulder, Colorado.
Nonuse to any degree is a serious problem. It is a dilemma for the librarian in that the nonuser does attain his degree and oftentimes does it quite handily but without the library. There are certain obvious explanations, such as the stereotyped mass education encountered at the freshman and sophomore levels at most universities, or the many "lab" courses in the sciences. But these do not fully explain library nonuse in colleges that profess such things as the procreation of well-rounded graduates, the liberal arts, independent study, honors programs, seminars, and the annual spending of millions of dollars on library resources.

The study described in this paper grew out of the above concerns and is based on a campus-wide census of library use taken during 1968 at Rensselaer Polytechnic Institute. ${ }^{1}$ The census, involving nearly 3,000 students, identified 239 who termed themselves as nonusers and some 1,100 who had used the library "a few times." Some of the "few times" users showed, through a lack of opinion on library services and facilities, that possibly a number of nonusers were also to be found in this group. (Presumably "few times" use 
carries less of a stigma with it than does nonuse.)

The following table from the 1968 census illustrates the incidence of nonuse and the finding that as the student advances in his college career he is more apt to use the library.

\section{Pattern of Library Use- Undergraduates-Percentages}

\begin{tabular}{|c|c|c|c|c|}
\hline $\begin{array}{l}\text { Pattern of } \\
\text { Library Use }\end{array}$ & Freshmen & Sophomores & Juniors & Seniors \\
\hline \multicolumn{5}{|l|}{ More than } \\
\hline \multicolumn{5}{|c|}{ More than 8 times } \\
\hline a semester & 26.9 & 27.4 & 31.5 & 33.1 \\
\hline A few times & 51.1 & 50.0 & 40.6 & 37.9 \\
\hline None & 15.0 & 9.6 & 6.3 & 1.8 \\
\hline
\end{tabular}

This latter conclusion is supported by the 6.8 percent figure for freshmen who claim to use the library more than once a week, while 27 percent of the seniors use it at that frequency.

In early 1970, 116 undergraduates who had indicated nonuse in the 1968 survey were still enrolled. From these 116 , a sample of thirty was randomly drawn. It was found that of the thirty, two had withdrawn in the last semester and one failed to be interviewed. Twenty-seven interviews were conducted during a two-week period, using a structured interview questionnaire. (Results and comments to selected questions are appended.)

One of the major findings of this study is that the use of the library, especially in the eyes of the nonuser, is strictly course-related, and unless he is "guided" in this manner, the inspiration or the inclination or the time are not there for the student to extend himself. A subjective conclusion is that the use or nonuse of the library is not based on intellectual capacity or the quality point average. (The nonuser is not an anti-intellectual; rather, he would appear to be as intellectually well-equipped as his library-user classmates.) The students interviewed were intelligent, concerned, and able to converse on topics not related to their academic pursuits. They state that they simply do not have the time to go very far beyond course requirements.

The unfortunate side of all this (apart from the effect it has on a librarian's ego) is that once the student leaves academia and enters a profession, his knowing how to use the literature could be very important. What may happen is that through nonuse or very likely misuse, the tyro-user will now assume that he is doing a fairly good job of finding possible solutions or applications to particular problems by scanning the current journals in his field or by some other inadequate method. Undoubtedly this accounts for some of the redundancy in research which has been estimated in the February 1964 issue (p. 377) of the New Scientist in the area of 10 percent to 20 percent. Millions of dollars in grants and man-hours are involved.

Further, it is worth noting that in Great Britain's Advisory Council on Scientific Policy Survey, 22 percent of the research and development Ph.D. respondents stated that they had carried out research which they subsequently discovered had already been done by someone else. Twenty-six percent of the nearly 3,000 scientists surveyed went on the record as having met an obstacle or delay in their research which they could have avoided if the relevant results of current or past research had been known to them. ${ }^{2}$

Personal case histories of duplicated research or of the misuse and nonuse of the literature are well known to most librarians. For that matter, how often is it that what we in librarianship consider at first glance as innovative frequently has been done before, as is revealed through a careful perusal of library literature? Although somewhat justifiable in the humanities for the varying qualities of research, it has been stated that 
"approximately 1 out of 20 doctoral candidates in English and American literature is preparing a dissertation which duplicates a previous study...."3

When he leaves the university, the student should have justified confidence in his ability to use the literature. It has certainly been called for before-for example, the recent National Academy of Sciences report recommends, "the training of all students as well as faculty (throughout their college careers if feasible) in the use of the increasingly complex array of existing library and information services." ${ }^{4}$

Also, the unpublished results of the "Survey of Opinion of Practicing Engineers" show that the practicing engineer is concerned with the effective use of literature.$^{5}$ To quote the report:

$\mathrm{He}$ (the practicing engineer) apparently feels that library and literature use facility is an asset and an essential requirement for fully effective practice by any engineer. In school he didn't learn much of what he feels he should know about getting at engineering results reported in the literature, and since then has had to do some digging in unfamiliar ground applying uncertain, uneasy methods. In school, also, he was given no inkling of the importance of engineering literature, and how to use it, how to get at it as a needed tool in engineering practice.

If he had the decision he would recommend that his school give emphasis to the teaching of techniques in library and literature use, and in the basic literature resources of specific engineering fields resulting in easy familiarity with such resources on the job.

These conclusions are over fifteen years old and only strengthen the critical need for educating the university library user in the effective use of the literature in the 1970s.

As a solution for limiting nonuse (which emphasizes what has already been called for in many user studies) it is recommended that faculty involve the use of the literature by students in research or problem-solving assignments whenever possible. In other words, it is hoped that improvements continue to be made over the time of Abelard when:

... successive generations of laborious and studious men .... consented for centuries to grow pale over a small number of texts, always the same, re-read (outloud to classes by the faculty) and commented on to satiety, gnawing, as it were, the same bone forever. $^{6}$ (parentheses mine)

In acknowledgment of the likely chance the above recommendation will be met with little enthusiasm from some faculty, an alternate recommendation is the preparation and presentation, on either a free or credit basis, of imaginative lectures by librarians (ideally in collaboration with the faculty or, if necessary, alone) on the use of the various literature sources. Librarians need to take the offensive to show at the minimum that the economics of duplicated research is a serious matter and that the reduction of this is only to be accomplished by researchers who appreciate through the literature what has been done and what is being done in the particular area in which they are working.

Furthermore, librarians should study the library requirements of the student and concern themselves with the student's preparedness at present and in the future to interact with the library. For example, to ask and answer such questions as what can be done to improve the student's plight in not fully utilizing library resources?; what are the library needs of the student which are now unsatisfied?; and what are the necessary steps to arrive at student library use satisfaction?

\section{APPENDIX}

Selected Tabulation and Commentary of Nonuser Interviews

The mathematical mean cumulative Quality Point Average (QPA) for the twen- 
ty-seven respondents, spread out over a normal appearing distribution of high, average, or low academic achievement, is 2.5. This is slightly higher than the overall QPA for the "average" Rensselaer student, which is 2.4. It is worth noting that had the total sample of thirty been available for interviewing, the QPA would have been 2.4 for the sample. The QPA distribution for the twenty-seven ranged from 1.6 to 3.4 out of a possible 4.0 .

QUESTION: If you are not a graduate student, do you intend to do graduate study?

\section{No $22 \%$ Yes $78 \%$}

The implication here should be evident. If anywhere, certainly in graduate school it is requisite that the student become familiar with the current and past advances in his field at least. The library will very likely have to be used.

QUESTION: Did your high school have a library?

\section{No $0 \%$ Yes $100 \%$}

If Yes, did you use the high school library more than you use the RPI library?

No $37 \%$ Yes $63 \%$

\section{Comments:}

"More need to use the high school library . . . at Rensselaer, through first three years at least, no need."

"Had to use it to get good grades."

"I was more library-oriented then."

"In high school it was a requirement ... I had more free time ... could read more on my own time. ..."

QUESTION: Did you use the public library in your community?

No $22 \%$ Yes $78 \%$

If $Y e s$, did you use the public library more than you use the RPI library?

No $24 \%$ Yes $76 \%$

\section{Comments:}

"I did more reading for enjoyment."

"I used the public library mainly to get books for pleasure . . . something I haven't done since I've been at RPI."

"I needed to use the library ... or sometimes went there to kill time by going in and browsing."
"Used it for high school assignments, for example, in senior year for two weeks every day was spent in public library on research."

"Would go to public library ... read odds and ends about science and other things of interest."

Quite clearly from the foregoing answers and comments, it can be said that the present "nonusers" were users and often frequent users of either the public or secondary school libraries.

QUestion: Should the RPI Library offer instruction in the use of the library?

\section{No $52 \%$ Yes $48 \%$}

\section{Comments:}

"No, not necessary-most have already had it ... they can always ask at the desk ... no sense of bringing everyone in."

"No, not worth it because not needed (only for graduate work) ... . often freshmen realize they don't need to use the library ... then they have no desire to learn library use."

"Yes, and I would take it . . . probably be an easy course."

"The library pamphlet is as effective as anything .... if you press for library use instruction, you'll find apathy."

QUESTION: Do you know any librarians? Very briefly, what is your general opinion of them?

Helpful but not capable 14\%

Helpful and effective 57\%

Professionals doing a professional job $17 \%$

Do not know any librarians $12 \%$

\section{Comments:}

"Most librarians I knew from high school were former teachers of mine that assumed a less demanding job, but were still involved in education."

"Helpful, but not professionals . . . just women who came in to help out in the library."

"In high school just monitors, discipline enforcers ... more helpful in public library." 
QUESTION: If you were assigned the job of developing a new process or a new procedure, would you be apt to consult the literature as to what had already been done?

No $0 \%$ Yes $100 \%$

Would you know how to go about this?

No $56 \%$ Yes $44 \%$

Whom would you ask for guidance to find already available information?

\begin{tabular}{|c|c|c|}
\hline Faculty & $39 \%$ & $\begin{array}{l}12 \text { times first to be } \\
\text { consulted }\end{array}$ \\
\hline Classmates & $12 \%$ & $\begin{array}{l}3 \text { times first to be } \\
\text { consulted }\end{array}$ \\
\hline Librarian & $31 \%$ & $\begin{array}{l}\text { never first; } 9 \text { times } \\
\text { second to be } \\
\text { consulted }\end{array}$ \\
\hline
\end{tabular}

Researchers in that field $\quad 18 \%$

The respondents who answered yes to knowing how to go about consulting the literature were not always fully confident they would know just how to go about it. For example:

\section{Comments:}

"Yes, I have a vague idea of how to."

"Yes, basically, I think I could."

"I would ask either faculty or librarian ... if general, librarian, if technical, faculty."

QUESTION: What do you think your professors, in general, think about using the library?

$14 \%$ recommend it

$11 \%$ have reserve books there

$8 \%$ make assignments to use it

$5 \%$ are opposed to it

$46 \%$ are neutral or noncommital

$16 \%$ do not place much value on it

Comments:

"In general, if you go on the times it is mentioned, the faculty are not too hot on it."

"They don't say anything about the use of the library."

"Professors will make reference to books, but few students will go to look these up."

"From time to time a professor will mention a reference, but generally understands that it will not be looked up. It's a matter of time ... . they do it to be cool."
"May be opposed to it because they want us to do work independently, i.e., not from a book in the library. For example, the 7-page solution to an assigned problem was found by students in a library book. The professor had used it as a 'source' for the problem."

QUESTION: Please give me your opinion of this quote, "The library is the heart of the university." Do you regard it as:
$2 \%$ true
$4 \%$ false
$46 \%$ not applicable to RPI
$40 \%$ true on some campuses
$8 \%$ a nice ideal, but unrealistic

\section{Comments:}

"Almost all assignments at RPI can be done without outside references. The library is not essential. More outside assignments should be given in every course to make the library more important."

"Certainly not here ... the professors are the heart of the university."

"Would be true of a library on a liberal arts campus . . . there they need various sources for comparison ... . we buy all ours at the bookstore."

QUESTION: How would you term your pattern of use of the Rensselaer Library? (Note that two years ago all the respondents had indicated nonuse of the library. This again bears out the claim that as the student progresses in his academic life he is apt to make use of the library.)

$22 \%$ more than once a week

11\% more than 8 times a semester

$22 \%$ few times a semester

$45 \%$ very seldom, or never

If you checked either of the last two above, what in your opinion is the reason?

$89 \%$ no need

$11 \%$ poor collection

\section{Comments:}

"Now I use it frequently . . . in previous semesters almost never . . . have found it a good place to study and get books that help explain material covered in class."

"Nothing brings you to the library ... . no habit ... no assignments made .. no pressure on part of faculty." 
"Very seldom or never in first two years ... now I come in for journals and newspapers and technical works."

"Most courses have texts with all the information in them. Once you know Ohm's law, you don't need to look it up. The main difference between liberal arts and the sciences $=$ no differences to Ohm's law, while criticism on topics in liberal arts is varied. ..."

"Go to frat brothers for information on courses ... no need for library."

\section{REFERENCES}

1. John Lubans, Jr., "Student Use of a Technological University Library," IATUL Proceedings 4:7-13 (July 1969).

2. Correspondence from Dr. Wood of the Department of Education and Science, National Lending Library of Science and Technology, Great Britain, 17 June 1970.

3. The Bowker Bulletin (Sept. 1968), p.4.

4. Scientific and Technical Communication: A Pressing National Problem and Recommendations for Its Solution. A Report by the Committee on Scientific and Technical Communication of the National Academy of
Sciences, National Academy of Engineering. National Academy of Sciences, Washington, D.C., 1969, p.62.

5. Sponsored by the American Society for Engineering Education, Engineering School Libraries Committee, as reported by Edward A. Chapman, in his Report on ASEE Engineering Literature Project (June 1953) (unpublished).

6. Gabriel Compayré, Abelard and the Origin and Early History of Universities (New York: AMS Press, 1969), p.187. 